\title{
Kajian Sanitasi Lingkungan Pemukiman di Bantaran Sungai Musi Kota Palembang
}

\author{
Inoy Trisnaini ${ }^{1^{*}}$, Haerawati Idris ${ }^{1}$, Imelda Gernauli Purba ${ }^{1}$ \\ ${ }^{1}$ Fakultas Kesehatan Masyarakat Universitas Sriwijaya, Palembang \\ *Corresponding author: inoytrisnaini@gmail.com \\ Info Artikel : Diterima November 2018 ; Disetujui April 2019 ; Publikasi Oktober 2019
}

\begin{abstract}
ABSTRAK
Latar belakang: Budaya membangun rumah di bantaran sungai apabila tidak diiringi dengan pemeliharaan sanitasi lingkungan, berpotensi mengakibatkan pencemaran sungai. Kondisi ini juga dapat menghasilkan berbagai permasalahan sanitasi lingkungan pada permukiman di bantaran sungai oleh tingginya aktivitas di wilayah bantaran sungai serta buangan rumah tangga. Kondisi ini yang tampak di Kecamatan Sebrang Ulu I Kota Palembang Propinsi Sumatera Selatan. Sehingga tujuan penelitian ini ialah untuk mengkaji karakteristik sanitasi lingkungan pemukiman serta program dan kebijakan yang berlaku bagi pemukiman di bantaran Sungai Musi Kecamatan Sebrang Ulu I Kota Palembang.

Metode: Penelitian ini menggunakan mix method, yaitu pengumpulan data dilakukan secara kuantitatif yaitu analisis spasial menggunakan Geographic Information System (GIS), serta kualitatif melalui observasi dan wawancara. Penelitian dilakukan di 6 Kelurahan di Kecamatan Sebrang Ulu I Kota Palembang, dengan sampel sebanyak 150 orang warga dan 13 orang informan yang berasal dari masing-masing kelurahan serta petugas dinas kesehatan.

Hasil: Kondisi sanitasi sumber air dan SPAL seluruh responden tidak memenuhi syarat kesehatan. Mayoritas jamban keluarga $(96,7 \%)$ dan tempat penampungan sampah $(92,7 \%)$ yang dimiliki responden dalam kondisi tidak memenuhi syarat kesehatan. Program penyehatan lingkungan pemukiman khususnya rumah sehat yang diterima oleh masyarakat yang tinggal di bantaran Sungai Musi ialah berupa kunjungan oleh petugas kesehatan setempat. Serta tidak adanya kebijakan terkait pemukiman di bantaran Sungai Musi Kecamatan Sebrang Ulu I Kota Palembang

Simpulan: Masih buruknya kondisi sanitasi dasar di Pemukiman bantaran Sungai Musi di Kecamatan Sebrang Ulu I Kota Palembang, serta belum optimalnya program penyehatan lingkungan pemukiman yang telah dilakukan oleh petugas kesehatan setempat.
\end{abstract}

Kata kunci: sanitasi; pemukiman; bantaran sungai; sistem infromasi geografis

\section{ABSTRACT}

Title: Study of Settlement Environmental Sanitation in The Bank Of Musi River, Palembang City

Background: The culture of building houses on river banks if not accompanied by the maintenance of environmental sanitation could potentially cause pollution in the river, as well as generate various environmental sanitation problems in settlements along the riverbanks. This was due to the high level of activity in the river banks as well as household discharges, which disrupts the aesthetics and function of the river. This condition was also evident in the Sebrang Ulu I Subdistrict, Palembang City, South Sumatra Province.So the purpose of this study is to examine the sanitation characteristics of the residential environment and the programs and policies that apply to settlements on the banks of the Musi River, Sebrang Ulu I District, Palembang City.

Methods: This study uses the mixed method. Data collection is carried out quantitatively, namely spatial analysis using Geographic Information System (GIS), a qualitative manner through observation and interviews. The study was conducted in 6 Outlands in Sebrang Ulu I Sub-District, Palembang City, with a sample of 150 residents and 13 informants from each of the outpatients and health service officers. 
Results: The sanitation conditions of water sources and SPAL all respondents did not meet health requirements. The majority of family latrines (96.7\%) and garbage shelters (92.7\%) owned by respondents in conditions do not meet health requirements. The program to restructure the residential environment, especially the healthy houses received by the people living on the banks of the Musi River, is in the form of visits by local health workers. The absence of policies related to settlements on the banks of the Musi River in the Sebrang Ulu I SubDistrict, Palembang City

Conclusions: The poor condition of basic sanitation in the settlements of the Musi River banks in the Sebrang Ulu I Sub-district, Palembang City, as well as the lack of optimal environmental sanitation programs that have been carried out by local health workers.

Keywords: sanitation; settlement; river bank; geographic information system

\section{PENDAHULUAN}

Budaya membangun rumah di pinggiran sungai mengakibatkan pencemaran pada sungai, serta menghasilkan berbagai permasalahan sanitasi lingkungan pada permukiman di bantaran sungai. Hal ini diakibatkan oleh buangan rumah tangga sehingga mengganggu estetika dan fungsi sungai.Kondisi ini juga tampak di Kecamatan Sebrang Ulu Kota Palembang Propinsi Sumatera Selatan. Sedangkan dari segi sarana dan prasarana sanitasi lingkungan daerah ini dapat dinilai sangat kurang.UU No 4/1992 tentang Perumahan dan Permukiman pasal 5 menyebutkan, setiap warga negara berhak untuk menghuni rumah yang layak dengan lingkungan yang sehat, aman, serasi, dan teratur. ${ }^{1}$ Kecamatan Sebrang Ulu I termasuk ke dalam 3 besar kecamatan dengan tingkat kepadatan penduduk tertinggi di Kota Palembang berdasarkan Profil Kesehatan Tahun

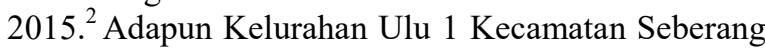
Ulu 1 Kota Palembang memiliki pola pemukiman yang padat, berada pada bantaran sungai. Tata letak bangunan mengikuti garis tepi sungai, jarak bangunan bervariasi, dan tidak beraturan, dan rata-rata jaraknya berdekatan. Banyak area basah di tepi sungai berbentuk genangan dan kumuh, serta tingginya aktivitas masyarakat di bantaran Sungai Musi di lingkungan pemukiman.

Pada bagian hulu aliran Sungai Musi terdapat wilayah pemukiman padat di Kota Palembang dengan aliran Sungai Musi yang melalui pemukiman tersebut, dimana aktivitas warga di perairan sungai masih cukup tinggi, termasuk aktivitas mencuci, mandi dan buang air besar, dimana tidak sedikitnya masyarakat yang membuang sisa makanan, sampah dan kotoran atau tinja, baik kotoran manusia maupun hewan, bahkan termasuk aktivitas pencucian kapal. Tingginya aktivitas di perairan sungai tentunya juga dapat memberikan pengaruh terhadap kualitas air sungai. Tentunya kondisi ini akan berpengaruh terhadap masyarakat yang tinggal di bantaran sungai tersebut, mengingat masih banyaknya aktivitas masyarakat di perairan sungai.

Penelitian oleh Inoy mengenai status pencemaran Sungai Musi khususnya di wilayah Sebrang Ulu dan Sebrang Ilir Kota Palembang, dengan menggunakan indikator fisik dan biologi menunjukkan bahwa perairan sungai di wilayah tersebut termasuk ke dalam kategori buruk (C) yang diantaranya disebabkan oleh padatnya pemukiman serta tingginya aktivitas warga di bantaran sungai. ${ }^{3}$ Sehingga tujuan dari penelitian ini ialah untuk mengkaji lebih dalam mengenai kondisi sanitasi pemukiman di bantaran Sungai Musi Kota Palembang.

\section{MATERI DAN METODE}

Penelitian ini menggunakan mix method, yaitu pengumpulan data dilakukan secara kuantitatif serta kualitatif. Data kuantitatif dikumpulkan melalui observasi sarana sanitasi dasar yang meliputi air bersih, jamban sehat, penampungan sampah serta pembuangan air limbah. Data kualitatif dikumpulkan melalui wawancara mengenai kebijakan-kebijakan terkait pemukiman di bantaran Sungai Musi Kota Palembang.

Penelitian dilakukan di Kecamatan Sebrang Ulu I yang terdiri dari 5 kelurahan yaitu Kelurahan 1 Ulu, Kelurahan 2 Ulu, Kelurahan 3-4 Ulu, Kelurahan 5 Ulu, dan Kelurahan 7 Ulu, Kota Palembang. Pemilihan wilayah Sebrang Ulu I dilakukan dengan pertimbangan Kecamatan Sebrang Ulu I termasuk ke dalam 3 besar kecamatan dengan tingkat kepadatan penduduk tertinggi di Kota Palembang berdasarkan Profil Kesehatan Tahun 2016.

Populasi penelitian adalah seluruh penduduk yang tinggal di Kecamatan Sebrang Ulu I yaitu berjumlah 187.245 jiwa. Besar sampel ditentukan dengan menggunakan rumus estimasi ${ }^{4}$ :

$$
\mathrm{n}=\frac{z_{1-\alpha / 2}^{2} \mathrm{P}(1-\mathrm{P}) \mathrm{N}}{\mathrm{d}^{2}(\mathrm{~N}-1)+z_{1-\alpha / 2}^{2} \mathrm{P}(1-\mathrm{P})}
$$

Perhitungan diperoleh jumlah sampel ialah 125, dan untuk menghindari drop out maka jumlah sampel ditambahkan 10\% menjadi 150 sampel. Pengambilan sampel menggunakan probability proportionate to size (PPS), berikut rumus yang digunakan ${ }^{5}$ :

$$
\mathrm{n}_{i}=\frac{\mathrm{N}_{i}}{\mathrm{~N}} \times \mathrm{n}
$$

Maka perhitungan sampelnya ialah sampel Kecamatan Ulu 1 sebanyak 25 sampel, Kecamatan Ulu 2 sebanyak 25 sampel, Kecamatan Ulu 3-4 
sebanyak 40 sampel, Kecamatan Ulu 5 sebanyak 42 sampel dan KecamatanUlu 7 sebanyak 18 sampel.

Informan penelitian ialah petugas dinas kesehatan, petugas puskesmas serta warga masyarakat.

Pengolahan dan Analisis Data

a. Data Kuantatif

Analisis data ialah analisis spasial dengan metode overlay peta atau pertampalan peta melalui Sistem Informasi Geografis (SIG) program Arc. View. Data hasil survei menghasilkan peta karakteristik sanitasi dasar yang meliputi akses air bersih, jamban sehat, penampungan sampah serta pembuangan air limbah

b. Data Kualitatif.

Analisis kualitatif terkait program serta kebijakan sanitasi lingkungan pemukiman. Data yang diperoleh melalui wawancara akan dibuat dalam bentuk matriks hasil wawancara selanjutnya diinterpretasi dan disimpulkan.

\section{HASIL DAN PEMBAHASAN}

\section{Sanitasi Sumber Air Bersih}

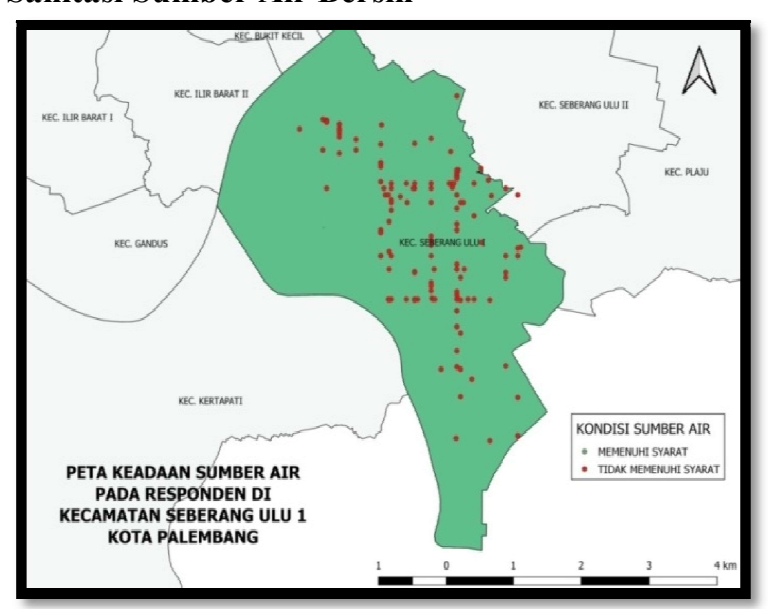

Gambar 1 serta hasil observasi menunjukkan bahwa (100\%) seluruh sumber air sehari-hari yang yang digunakan oleh responden penelitian tidak memenuhi syarat kesehatan. Sebab warga yang menjadi responden pada penelitian ini menggunakan air sungai sebagai sumber air untuk kebutuhan seharihari mereka. Berbeda dengan penelitian yang dilakukan oleh Wijaya air bersih yang digunakan masyarakat yaitu air bersih PDAM untuk konsumsi sehari-hari. Permukiman dengan kepadatan bangunan yang tinggi menjadi salah satu penyebab masyarakat.

\section{Sanitasi Jamban Keluarga}

Tabel 1. Kondisi Sanitasi Jamban Keluarga

\begin{tabular}{lcc}
\hline Sanitasi & Frequenci & Persen (\%) \\
\hline Tidak & 145 & 96.7 \\
$\begin{array}{l}\text { Memenuhi } \\
\text { Syarat } \\
\text { Memenuhi }\end{array}$ & 5 & \\
$\begin{array}{l}\text { Syarat } \\
\text { Total }\end{array}$ & 150 & 3.3 \\
\hline
\end{tabular}

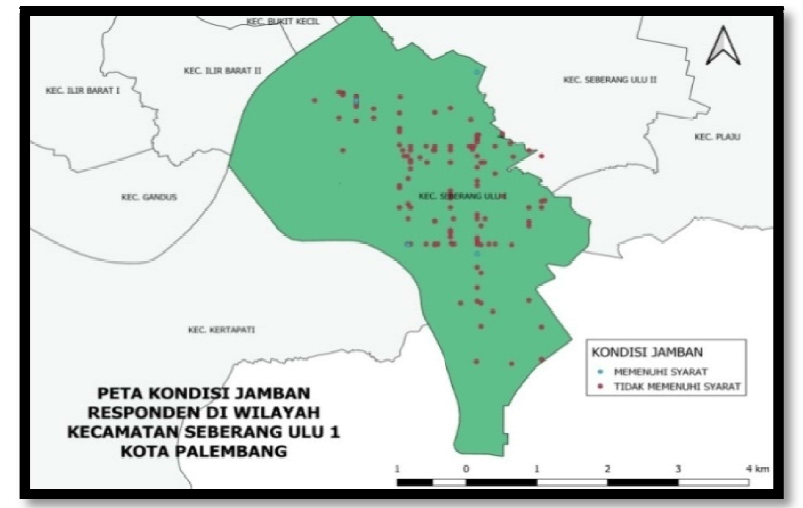

Gambar 2. Peta Gambaran Sanitasi Jamban

Pada Tabel 1 dan Gambar 2, mayoritas jamban keluarga yang dimiliki responden dalam kondisi tidak memenuhi syarat kesehatan $(96,7 \%)$. Kondisi ini sepadan dengan penelitian Wijaya bahwa pemukiman Cihampelas Bandung yang termasuk ke dalam pemukiman kumuh. Kondisi bangunan fasilitas MCK menggunakan fasilitas seadanya, menggunakan atap asbes yang sebagian sudah mengalami kerusakan, dinding fasilitas MCK ada yang menggunakan bentuk semi permanen, dan saluran pembuangan seadanya asal bisa mengalir Sedangkan masalah pembuangan limbah kotoran manusia dapat berpotensi terhadap pencemaran sungai. ${ }^{6}$

Hasil penelitian oleh Yuliana Irnadi pemukiman penduduk bantaran Sungai Karang Mumus Kelurahan Bandara Samarinda menunjukkan bahwa menurunnya kualitas air Sungai Karang Mumus adalah karena masyarakat setempat masih membuang sampah ke sungai, penggunaan jamban di atas sungai sehingga kotoran tinja maupun limbah cair masuk ke sungai dan membuat sungai tersebut kondisinya kotor. ${ }^{7}$

Sebagai salah satu alternatif solusi terkait pembuangan tinja yang layak ialah pembuangan limbah domestik diarahkan menggunakan sistem septik tank dengan resapan/filter, sebagian dengan septik tank tanpa resapan. Dengan proses pengolahan langsung ke dalam IPLT yang sudah ada (menggunakan truk tinja) dan menggunakan sistem SPAL. Pengelolaan dan pembuatan fasilitas domestik yang melibatkan partisipasi masyarakat dengan dukungan bantuan pemerintah.

\section{Sanitasi Tempat Penampungan Sampah}

Tabel 2. Kondisi Sanitasi Tempat Penampungan Sampah (TPS)

\begin{tabular}{lcc}
\hline Kategori & Frekuensi & $\begin{array}{c}\text { Persen } \\
(\%)\end{array}$ \\
\hline $\begin{array}{l}\text { Tidak } \\
\text { Memenuhi }\end{array}$ & 139 & 92.7 \\
$\begin{array}{l}\text { Syarat } \\
\text { Memenuhi }\end{array}$ & 11 & \\
$\begin{array}{l}\text { Syarat } \\
\text { Total }\end{array}$ & 150 & 7.3 \\
\hline
\end{tabular}


Tabel 2 menunjukkan bahwa mayoritas tempat penampungan sampah yang dimiliki respon tidak memenuhi syarat kesehatan $(92,7 \%)$. Penelitian oleh Hakki di Kelurahan Pasar Krui, sebanyak 27 (90\%) responden membuang sampah di Sungai Tuwak karena lebih dekat dengan permukiman penduduk daripada tempat pembuangan sampah umum serta 30 $(100 \%)$ responden menyatakan terjadi pencemaran Sungai Tuwak karena terlihat air sungai bercampur sampah. ${ }^{8}$ Sedangkan sungai sangat berguna demi kelangsungan setiap makhluk hidup yang ada di dunia ini untuk menunjang kebutuhan hidupnya sehari-hari.

Sampah seringkali menjadi salah satu permasalahan utama pemukiman yang berada di bantaran sungai, seperti kondisi pemukiman di tepi Sungai Kelurahan Pelita, Kecamatan Samarinda Ilir, terdapat variabel fisik dan non fisikyang berada pada kualitas jelek yaitu persampahan dan penyakit social. ${ }^{9}$ Begitupun kondisi yang terjadi di Pemukiman kumuh tepian Sungai Kecamatan Kolaka, Sulawesi Tenggara, dapat disimpulkan sebagian besar kondisi yang ada termasuk kategori kumuh, yaitu: sanitasi lingkungan, persampahan dan saluran air hujan. Kebiasaan penduduk membuang sampah, air kotor dan jamban di sungai, menjadikan sungai tercemar. ${ }^{10}$

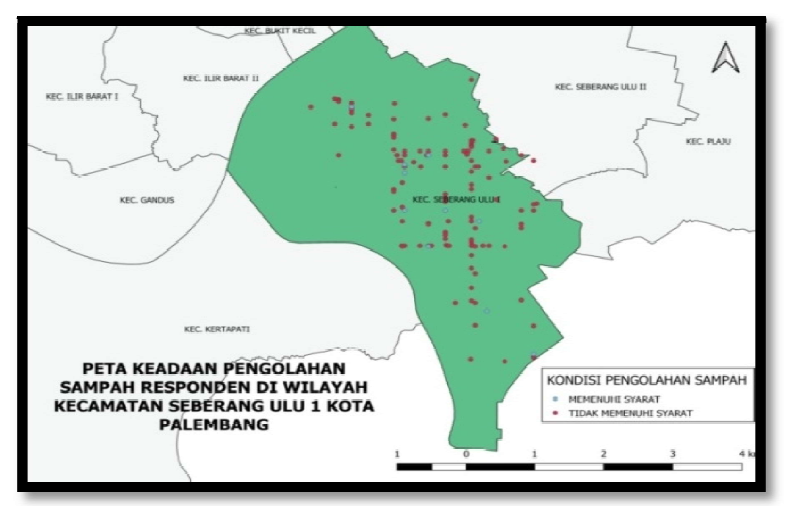

Gambar 3. Sanitasi Sarana Tempat Penampungan

Pada Gambar 3 di atas ini juga menunjukkan masih banyak waga Kecamatan Sebrang Ulu 1 yang melakukan pengelolaan sampah rumah tangga dengan baik. Adapun sebagai salah satu alternatif solusi permasalahan sampah di wilayah ini ialah melalui penyediaan spot-spot bak sampah di setiap kawasan, pengolahan sampah menjadi sampah organik dan ditempatkan TPS untuk menampung sampah-sampah rumah tangga sementara. Namun untuk mengatasi masalah ini harus diawali dengan adanya kesadaran dari masyarakat bahwa jangan sampai lagi ada anggapan membuang sampah di sembarang tempat. ${ }^{11}$

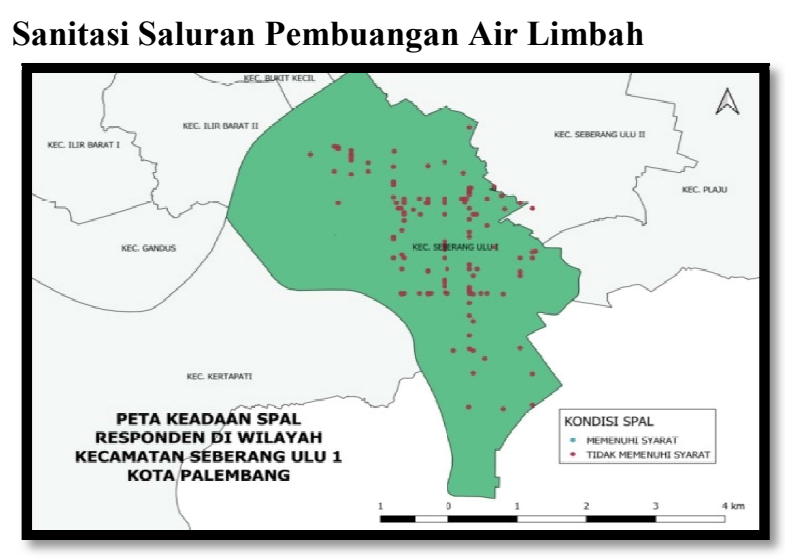

Gambar 4.Sanitasi Saluran Pembuangan Air Limbah

Hasil penelitian yang terlihat pada Gambar 4 bahwa kondisi sanitasi saluran pembuangan air limbah seluruh responden tidak memenuhi syarat. Penelitian oleh Riogilang di Kampung Sanger Manado, memberi catatan akan pentingnya saluran drainase air limbah, dimana dengan dibangunnya sistem drainase yang memenuhi syarat menjadikan lingkungan pemukiman menjadi lebih sehat, tertata dan berkurangnya sumber penyakit dari sampah yang menyumbat jalannya air, serta dapat mengatasi banjir di daerah tersebut. ${ }^{12}$

Kondisi pemukiman di Kecamatan Sebrang Ulu yang berupa rumah panggung dan terletak di bantaran sungai justru memicu pencemaran dengan adanya warga yang menyalurkan air limbah bahkan sampah langsung ke sungai. Pada dasarnya tidak ada yang salah dengan konsep rumah panggung sebab hal ini merupakan salah satu kearifan local daerah bahkan dalam pembangunan pemukiman, namun pentingnya didukung dengan pengelolaan sanitasi pemukiman yang baik. ${ }^{13}$

\section{Program Penyehatan Lingkungan Pemukiman}

Hasil wawancara dengan perwakilan masyarakat yang tinggal di Kelurahan Sebrang Ulu I, 2, 3-4, 5, 6 dan 7 terkait program penyehatan lingkungan pemukiman khususnya mengenai rumah sehat secara keseluruhan. Beberapa informan lainnya menyatakan bahwa mereka pernah mendapat kunjungan dari petugas kesehatan baik oleh puskesmas maupun dinas kesehatan dan mendapatkan pertanyaan serta sedikit informasi mengenai sumber air minum. Namun selama ini mereka tidak pernah mengetahui dan merasakan program-program mengenai penyehatan lingkungan pemukiman khususnya mengenai rumah sehat.

Kurangnya pengetahuan dan pemahaman masyarakat terhadap rumah sehat tidak hanya akan berpengaruh buruk terhadap kesehatan mereka namun jika rentan menyebabkan terjadinya pencemaran di wilayah bantaran sungai. Sedangkan pengetahuan merupakan faktor yang sangat menentukan sikap dan status kesehatan seseorang, seperti penelitian oleh 
Pradono bahwa 49,7\% status kesehatan ditentukan oleh variasi pengetahuan tentang kesehatan lingkungan. ${ }^{14}$ Zanuardi melalui penelitiannya menyimpulkan bahwa setidaknya beberapa potensi permasalahan yang dapat muncul pada pemukiman kumuh padat penduduk meliputi bangunan, jalan lingkungan, drainase, pelayanan air minum, pengelolaan air limbah, pengelolaan sampah dan proteksi kebakaran. ${ }^{15}$

Kawasan kumuh itu sendiri ialah kawasan dimana rumah dan kondisi hunian masyarakat di kawasan tersebut sangat buruk. Rumah maupun sarana dan prasarana yang ada tidak sesuai dengan standar yang berlaku. ${ }^{16}$ Pendirian bangunan seharusnya memperhatikan garis sempadan sungai. Selain itu terdapat vegetasi hijau yang terlihat dilingkungan sekitar maupun ruang terbuka baik hijau maupun non hijau. ${ }^{17}$

\section{Kebijakan Penyehatan Lingkungan Pemukiman}

Hasil wawancara pada beberapa informan menyatakan ketidaktahuannya mengenai izin pendirian bangunan. Berdasarkan Peraturan Pemerintah No 35 Tahun 1991 Tentang Sungai Pasal 26, bahwa mendirikan, mengubah atau membongkar bangunan-bangunan di dalam atau melintas sungai hanya dapat dilakukan setelah memperoleh ijin dari pejabat yang berwenang. ${ }^{18}$ Pendirian bangunan di wilayah bantaran sungai pada dasarnya diizinkan, tentunya harus memiliki izin serta memperhatikan aspek kelestarian dan kebersihan lingkungan sungai. Maka warga dilarang mencemari lingkungan sungai, seperti yang tertera pada pasal 27 PP No. 35 Tahun 1991, yaitu dilarang membuang benda-benda/bahanbahan padat dan/atau cair ataupun yang berupa limbah ke dalam maupun di sekitar sungai yang diperkirakan atau patut diduga akan menimbulkan pencemaran atau menurunkan kualitas air. ${ }^{18}$

Dinas kesehatan setempat menyatakan bahwa adanya program khusus mengenai rumah sehat, yang seharusnya pelaksanaannya terutama dilakukan oleh petugas puskesmas. Namun dari dinas kesehatan juga melakukan kunjungan dalam rangka program penyehatan lingkungan rumah. Berdasarkan keterangan dari petugas dinas kesehatan yang menjadi informan bahwa program penyehatan lingkungan yang dilaksanakan oleh dinas kesehatan dengan tenaga pelaksananya berupa penyuluhan mengenai rumah sehat. Serta dilakukan pembinaan kepada warga yang dinilai kondisi rumahnya kurang/tidak sehat.

Sedangkan untuk program yang berupa pembangunan fisik, seperti perbaikan rumah dan pembangunan jamban sehat, dinas kesehatan menyatakan program tersebut tidak lagi menjadi kewenangan mereka melainkan merupakan bagian dari program dinas PU. Aktivitas masyarakat di bantaran sungai yang jika tidak diawasi maka berpotensi menimbulkan pencemaran sungai. PP No 35 Tahun 1991 secara jelas telah mengatur dan melarang pembuangan sampah ke sungai.Selain itu permasalahan visual pada kawasan bantaran sungai sebenarnya dapat diselesaikan melalui solusi terkait dengan lingkungan, visual, perilaku warga serta regulasi. ${ }^{19}$

Kebijakan merupakan salah satu poin penting dalam perbaikan kondisi lingkungan pemukiman. Diperlukannya lembaga koordinasi dan pelaksana pengawasan dan pengendalian pemanfaatan ruang yang didukung dengan masyarakat setempat sebagai kekuatan pendukung implementasi kebijakan tata ruang. $^{20}$

\section{SIMPULAN}

Penelitian ini menyimpulkan: 1) Mayoritas jamban keluarga yang dimiliki responden dalam kondisi tidak memenuhi syarat kesehatan $(96,7 \%), 2)$ Mayoritas tempat penampungan sampah yang dimiliki respon tidak memenuhi syarat kesehatan $(92,7 \%), 3)$ Kondisi sanitasi saluran pembuangan air limbah seluruh responden tidak memenuhi syarat kesehatan, 4) Program penyehatan lingkungan pemukiman khususnya rumah sehat yang diterima oleh masyarakat yang tinggal di bantaran Sungai Musi ialah berupa kunjungan oleh petugas kesehatan setempat, 5) Tidak adanya kebijakan terkait pemukiman di bantaran Sungai Musi Kecamatan Sebrang Ulu I Kota Palembang, baik mengenai pendirian bangunan maupun mengenai penyehatan lingkungan pemukiman.

\section{DAFTAR PUSTAKA}

1. Undang-Undang Nomor 4 Tentang Perumahan dan Permukiman. Jakarta; 1992

2. Dinkes Kota Palembang. Profil Kesehatan Kota Palembang; 2015.

3. Trisnaini I, Kumalasari TN, Utama F. Identifikasi Habitat Fisik Sungai dan Keberagaman Biotilik SebagaiIndikator Pencemaran Air Sungai Musi Kota Palembang. Jurnal Kesehatan Lingkungan Indonesia 2018, 17(1): $1-8$.

4. Murti B. Desain dan Ukuran Sampel untuk Penelitian Kuantitatif dan Kualitatif di Bidang Kesehatan. Gadjah Mada University Press. Yogyakarta; 2010.

5. Notoatmodjo S. Metodologi Penelitian Kesehatan. Rineka Cipta. Jakarta; 2010.

6. Wijaya K, Permana AY, Suwanto N. Kawasan Bantaran Sungai Cikapundung Sebagai Pemukiman Masyarakat Berpenghasilan Rendah (MBR) di Kota Bandung. Jurnal Arsitektur 2017, $1(2): 57-68$.

7. Yuliana I. Studi tentang pengetahuan masyarakat Terhadap Kondisi lingkungan Pemukiman Penduduk di Bantaran sungai karang mumus Kelurahan bandara Samarinda. Ejournal SosiatriSosiologi, 2013, 1(1): 20-30.

8. Hakki W. Dampak pemanfaatan bantaran sungai terhadap Kualitas lingkungan di kelurahan pasar krui. Skripsi. Program Studi Pendidikan Geografi 
Jurusan Pendidikan Ilmu Pengetahuan Social Fakultas Keguruan dan Ilmu Kependidikan Universitas Lampung; 2015.

9. Sari NR, Khadiyanto P. Kualitas Lingkungan Permukiman di Tepi Sungai Kelurahan Pelita, Kecamatan Samarinda Ilir. Jurnal Teknik PWK 2014, 3(4): 1002-1012.

10. Amri N. Karakteristik Lingkungan Permukiman Kumuh Tepian Sungai Kecamatan Kolaka, Sulawesi Tenggara. Jurnal Jupiter 2013, XII(1): 110.

11. Purwanto N. Perilaku Sadar Lingkungan Pemukim Bantaran Sungai Jelai, Kabupaten Sukamara. Jurnal Pembangunan Wilayah dan Kota 2018, 14(1): $41-50$.

12. Riogilang H. Identifikasi dan pedampingan untuk mengatasi Masalah sanitasi pada Pemukiman kumuh di Kampung Sanger, Sario Manado. Jurnal LPPM Bidang Sains dan Teknologi 2016, 3(2): 54-63.

13. Kurnia W. Mutu Permukiman Bantaran Sungai di Banjarmasin. Jurnal Info - Teknik 2008, 9(1): 4350.

14. Pradono J, Sulistyowati N. Hubungan antara tingkat pendidikan, Pengetahuan Tentang kesehatan lingkungan, perilaku hidup Sehat
Dengan status kesehatan Studi Korelasi pada Penduduk Umur 10-24 Tahun di Jakarta Pusat. Buletin Penelitian Sistem Kesehatan 2014, 17 (1): 89-95.

15. Zanuardi A, Aulia RA, Hakim A. Model Identifikasi Karakteristik Permasalahan Kawasan Permukiman Kumuh di Wilayah Perkotaan (Studi Kasus : Permukiman Lette dan Pampang, Kota Makassar). Jurnal Sosial Ekonomi Pekerjaan Umum 2017, 9(2): 1-16.

16. Putro JW. Penataan Kawasan Kumuh Pinggiran Sungai di Kecamatan Sungai Raya. Jurnal Teknik Sipil UNTAN 2011, 11 (1): 19-34.

17. Raisya N, Pigawati P. Kajian Karakteristik Kawasan Pemukiman Kumuh Di Kampung Kota (Studi Kasus: Kampung Gandekan Semarang). Jurnal Teknik PWK 2015, 4(2): 267-281.

18. Peraturan Pemerintah RI No 35 Tentang Sungai. Jakarta; 1991.

19. Cesarin BT, Ginting C. Persepsi Masyarakat terhadap Permukiman Bantaran Sungai. Prosiding Temu Ilmiah IPLBI 2015 : 117-122.

20. Fitria TA. Revitalisasi Permukiman di Tepi Sungai Dengan Pendekatan Lanskap Berkelanjutan untuk Meningkatkan Kesehatan Lingkungan. Proceeding Health Architecture 2017, 1(1): 195-197. 